\title{
Assessment of potential implications of agricultural irrigation policy on surface water scarcity in Brazil
}

\author{
Sebastian Multsch ${ }^{1, a}$, Maarten S. Krol${ }^{2}$, Markus Pahlow ${ }^{3}$, André L. C. Assunção ${ }^{4}$, Alberto G. O. P. Barretto ${ }^{4}$, \\ Quirijn de Jong van Lier ${ }^{5}$, and Lutz Breuer ${ }^{1,6}$ \\ ${ }^{1}$ Institute for Landscape Ecology and Resources Management (ILR), Research Centre for BioSystems, \\ Land Use and Nutrition (iFZ), Justus Liebig University Giessen, Giessen, Germany \\ ${ }^{2}$ Water Engineering and Management, University of Twente, Enschede, the Netherlands \\ ${ }^{3}$ Department of Civil and Natural Resources Engineering, University of Canterbury, Christchurch, New Zealand \\ ${ }^{4}$ Luiz de Queiroz College of Agriculture (ESALQ), University of São Paulo, São Paulo, Brazil \\ ${ }^{5}$ Center for Nuclear Energy in Agriculture (CENA, University of São Paulo, São Paulo, Brazil \\ ${ }^{6}$ Center for International Development and Environmental Research (ZEU), \\ Justus Liebig University Giessen, Giessen, Germany \\ ${ }^{\mathrm{a}}$ current address: knoell Germany $\mathrm{GmbH}$, Mannheim, Germany
}

Correspondence: Lutz Breuer (lutz.breuer@umwelt.uni-giessen.de)

Received: 17 April 2019 - Discussion started: 14 May 2019

Revised: 26 November 2019 - Accepted: 15 December 2019 - Published: 21 January 2020

\begin{abstract}
Expanding irrigated cropping areas is one of Brazil's strategies to increase agricultural production. This expansion is constrained by water policy goals to restrict water scarcity to acceptable levels. We therefore analysed the trade-off between levels of acceptable water scarcity and feasible expansion of irrigation. The appropriateness of water use in agricultural production was assessed in categories ranging from acceptable to very critical based on the river flow that is equalled or exceeded $95 \%$ of the time $\left(Q_{95}\right)$ as an indicator for physical water availability. The crop water balance components were determined for 166842 subcatchments covering all of Brazil. The crops considered were cotton, rice, sugarcane, bean, cassava, corn, soybean and wheat, together accounting for $96 \%$ of the harvested area of irrigated and rain-fed agriculture. On currently irrigated land irrigation must be discontinued on $54 \%$ (2.3 Mha) for an acceptable water scarcity level, on $45 \%$ (1.9 Mha) for a comfortable water scarcity level and on $35 \%$ (1.5 Mha) for a worrying water scarcity level, in order to avoid critical water scarcity. An expansion of irrigated areas by irrigating all 45.6 Mha of the rain-fed area would strongly impact surface water resources, resulting in 26.0 Mha experiencing critical and very critical water scarcity. The results show in a spatially differentiated manner that potential future decisions re-
\end{abstract}

garding expanding irrigated cropping areas in Brazil must, while pursuing to intensify production practices, consider the likely regional effects on water scarcity levels, in order to reach sustainable agricultural production.

\section{Introduction}

In 2013 the Brazilian government took a step towards the consolidation of a national irrigation policy through the enactment of Law 12,787 (http://www.planalto.gov.br/ CCIVIL_03/_Ato2011-2014/2013/Lei/L12787.htm, last access: 25 November 2019), with two of the objectives being to encourage the expansion of irrigated areas and to increase productivity on an environmentally sustainable basis. According to Law 12,787, policy implementation would have to be based on regional and national plans estimating expansion potential and indicating suitable areas for the prioritisation of public investments. However, to date, a national plan has not yet been developed and the official study available to support the plan is expected to be fully reviewed in 2019 (FEALQ-IICA-MI, 2015). Underlying policy goals include striving for equitable socioeconomic development (VanWey et al., 2013), for a continued large role of biofuels in national 
energy production and for a strong agricultural sector serving national and international demands of commodities such as soybean (Dalin et al., 2012). One of the governing principles in this policy is the sustainable use and management of land and water resources for irrigation, thereby not negatively affecting communities or sacrificing water resources, unique ecosystems, and the services they provide (Alkimim et al., 2015; Castello and Macedo, 2016; Lathuillière et al., 2016).

The extent to which irrigation is a suitable measure to achieve these goals is debated in the literature. Both Fachinelli and Pereira (2015) and Scarpare et al. (2016) find that in the Paranaíba river basin, covering about $25 \%$ of the Brazilian Cerrado biome, irrigation increases sugarcane yield, in particular in projected expansion areas, but this increase is also in the central region of the basin where sugarcane production is already established. Irrigation shows the potential to reduce costs, thereby enhancing the economic viability of sugarcane expansion. Yet both studies caution not to compromise available water resources and hence to restrict irrigation practices to areas where water is sufficiently available, which, according to Scarpare et al. (2016), generally corresponds to most of the central and western portions of that basin. In a study on the Amazon region Lathuillière et al. (2016) identify that the best land-water management would be one that intensifies agricultural production by expanding cropland into pasture and considering irrigation while avoiding conflicts with downstream users such as electricity producers and reducing pressure on aquatic ecosystems in the Amazon basin. The expansion of rain-fed agriculture in southern Amazonia is known to reduce the water vapour supply to the atmosphere (Lathuillière et al., 2018). Lathuillière et al. (2018) note that this effect could slow down or be reversed by an increase in the vapour supply to the atmosphere following widespread irrigation, but this is not without consequences on surface or groundwater resources.

The Cerrado in central Brazil with a savannah climate is a region with both a strong trend over the last several years of advancing large-scale agribusinesses for agriculture and livestock and the potential for more sustainable land management (Dickie et al., 2016). For example, Alkimim et al. (2015) propose that it is possible to expand sugarcane production in Brazil by converting existing pasturelands into cropland without further environmental losses, whereby they estimate that an area of 50 Mha is moderately or highly suitable for sugarcane production. In another study, Strassburg et al. (2014) assess that current productivity of Brazilian cultivated pasturelands is one third of its potential and that increasing the productivity to one half of the potential would suffice to meet national demands for meat, crops, wood products and biofuels until at least 2040, thereby avoiding the additional conversion of natural ecosystems. Sparovek et al. (2015) analyse comprehensive scenarios with a spatially explicit land-use model for Brazilian agriculture production and nature conservation. They find that a substantial increase in crop production, using an area 1.5-2.7 times the current cropland area, is feasible with much of the new cropland being located on current pastureland.

Land use and land management affect the utilisation of water resources, so every strategy and decision with respect to land is also a strategy and decision with respect to water. This holds for both the precipitation-supplied water stored in the soil matrix (termed green water) and the water in streams, lakes, wetlands and aquifers (termed blue water) (Falkenmark, 1995). While Brazil may be considered wellendowed with water resources, these resources are unevenly distributed across the country. Hence, efficient, sustainable and equitable strategies must be developed, thereby considering the spatially and temporally varying water availability. To that end, Getirana (2016) points out that ineffective energy development and water management policies in Brazil have magnified the impacts of recent severe droughts, which include massive agricultural losses, water supply restrictions and energy rationing.

Metrics of water scarcity and stress have evolved from simple threshold indicators to holistic measures characterising human environments and freshwater sustainability (Damkjaer and Taylor, 2017). The Brazilian national water agency ANA (Agência Nacional de Águas) uses the availability of blue surface water in operational management, whereby the river discharge, partly delivered by regulated reservoir flows, is compared to water withdrawals. ANA distinguishes water scarcity classes based on the risk of river flow to fail to support environmental services (ANA, 2015).

In studying possible expansion of irrigated areas, as encouraged by the Brazilian government under Law 12,787, this paper addresses the trade-off between the choice of the level of blue-water scarcity that is deemed acceptable and the feasible expansion of the irrigated area complying with that limitation. In addressing this issue, we restrict the analysis to irrigation expansion on cropping areas in the production year 2012, representing the situation just before Law 12,787 came into effect in 2013.

Our assessment entails the following steps:

i. the spatially explicit calculation of green- and bluewater consumption for the main crops cultivated in Brazil for both rain-fed and irrigated production systems,

ii. the estimation of blue-water scarcity due to the bluewater consumption of a reference scenario (irrigated areas in 2012) and an expansion scenario, i.e. under the assumption that all rain-fed areas are irrigated, thereby considering surface water availability, and

iii. the spatially explicit analysis as to what extent expansion of irrigation areas is sustainable.

Our overall objective is to evaluate the feasibility of irrigation expansions in Brazil. We thereby investigate the following 
research question: is the expansion of irrigated areas, as encouraged by the Brazilian government, environmentally sustainable from a surface water resources point of view? The Cerrado biome, a region of significant agricultural expansion and a biodiversity hotspot (Mittermeier et al., 2005; Strassburg et al., 2017), is considered in particular detail.

\section{Data}

Precipitation, maximum and minimum temperature, solar radiation, relative humidity, and wind speed data for the production year 2012 were obtained from Xavier et al. (2016), who developed a daily gridded dataset for Brazil with a $0.25^{\circ} \times 0.25^{\circ}$ resolution of these meteorological variables based on 3625 rain gauges and 735 weather stations. In order to determine the required soil properties, data on bulk density, organic carbon content, and fractions of sand, silt and clay have been extracted from the ISRIC (International Soil Reference and Information Centre) SoilGrids $1 \mathrm{~km}$ database (Hengl et al., 2014).

Saturation and residual water content $\theta_{\mathrm{s}}$ and $\theta_{\mathrm{r}}\left(\mathrm{m}^{3} \mathrm{~m}^{-3}\right)$ and the parameters $\alpha$ and $n$ of the van Genuchten function (van Genuchten, 1980) were estimated using the level 3 pedotransfer function of Tomasella et al. (2000) for Brazilian soils, under the assumption that coarse- and fine-sand fractions have an equal share of the total sand content. The field capacity and wilting point were determined as soil water content at -33 and $-1500 \mathrm{kPa}$, respectively, following van Genuchten (1980). Soil types were determined using the nomenclature of the United States Department of Agriculture (USDA). Data on the harvested area and yield of nine main crops for the production year 2012 as provided by IBGE (Instituto Brasileiro de Geografia e Estatística) were utilised in this study. The crops considered are cotton, rice, sugarcane, Vigna spp. and Phaseolus spp. bean, cassava, corn, soybean, and wheat. Combined those nine crops account for $96 \%$ of harvested area (ha), $98 \%$ of production mass (tonne) and $90 \%$ of production value (Brazilian real) in Brazil in the year 2012 (IBGE, 2012). Planting and harvesting dates for the sub-regions considered were taken from Conab (2015). For some crops, multiple harvests per year are considered, following information provided by IBGE. Catchment-scale data on surface water supply were obtained from the ANA GeoNetwork (http://metadados.ana.gov.br/ geonetwork/srv/pt/main.home, last access: 25 November 2019). An overview of the underlying data is given in Table 1.

\section{Methods}

In order to assess water consumption of the potential expansion of irrigation, impacts on water scarcity and limits to irrigation expansion under scarcity thresholds, we applied a site-specific crop water balance model at the catchment scale.
To this end, high-resolution gridded data on climate and soil were combined with statistical information on irrigation management to run a countrywide daily crop water balance model for 166842 sub-catchments in Brazil to determine rain-fed and irrigated water requirements. The crops considered were cotton, rice, sugarcane, Vigna spp. and Phaseolus spp. bean, cassava, corn, soybean, and wheat.

\subsection{SPARE:WATER}

\subsubsection{Calculation of green- and blue-water consumption}

The open-source crop water balance and footprint model SPARE:WATER (Multsch et al., 2013) was used to determine green- and blue-water consumption in crop production. The tool was applied to investigate several topics related to water resources management in recent years, e.g. the predicted future irrigation demands and impact of technology in the Nile river basin (Multsch et al., 2017a), managing desalinated seawater use in agriculture in Saudi Arabia (Multsch et al., 2017b) and characterising groundwater scarcity caused by large-scale irrigation in the USA (Multsch et al., 2016).

First, the daily crop water balance was calculated at the $0.25^{\circ} \times 0.25^{\circ}$ grid level for each crop per growing season, utilising the gridded climate and soils data (see Table 1). Second, the contribution of crop production to the regional water balance at the level of municipalities was derived by multiplying crop water consumption per growing season, averaged over the grids in the municipality, with the respective municipal cropping area $\left(\mathrm{ha}^{-1}\right)$. Note that the information regarding irrigated areas and the fraction of irrigated area per crop was also available at the municipality level (Table 1). Thirdly, the total water consumption was determined per subcatchment, which was then contrasted with the water supply in each one of the 166842 sub-catchments and aggregated to the municipality level. These steps are shown in Fig. A1.

Consumptive water use was separated into the consumption of green $\left(\mathrm{CW}_{\mathrm{g}}\right)$ and blue $\left(\mathrm{CW}_{\mathrm{b}}\right)$ crop water in $\mathrm{m}^{3} \mathrm{ha}^{-1}$ at the grid level. To achieve this simulations were carried out twice for the entire country, once for purely rain-fed conditions (fraction irrigated $f=0$ ), to determine green-water consumption $\mathrm{CW}_{\mathrm{g}}$, and once for purely irrigated conditions (fraction irrigated $f=1) \mathrm{CW}_{\mathrm{b}}$, in order to determine additional blue-water consumption, following earlier work by Mekonnen and Hoekstra (2010) and Siebert and Döll (2010). The blue-water consumption was estimated as the difference between the two simulations.

$$
\begin{aligned}
& \mathrm{CW}_{\mathrm{g}}=\mathrm{ET}_{f=0} \\
& \mathrm{CW}_{\mathrm{b}}=\mathrm{ET}_{f=1}-\mathrm{ET}_{f=0}
\end{aligned}
$$

\subsubsection{Calculation of crop water balance}

In SPARE:WATER, the crop water balance is calculated based on the crop water balance model proposed by Allen 
Table 1. Data used in this study and respective sources.

\begin{tabular}{lll}
\hline Data type & Source & Spatial scale \\
\hline Climate data & Xavier et al. (2016) & $0.25^{\circ} \times 0.25^{\circ}$ \\
Soil data & Hengl et al. (2014) & $1 \mathrm{~km}$ \\
Crop production & IBGE (2012) Produção Agrícola Municipal (PAM) & Municipality $^{\mathrm{a}}$ \\
Crop coefficients (see Table A1) & Allen et al. (1998), Hernandes et al. (2014) & - \\
Planting and harvesting date (see Table A2) & Conab (2015) & - \\
Surface water supply & ANA (2016) & Catchment $^{\mathrm{b}}$ \\
Extent of irrigated areas & IBGE (2012) Produção Agrícola Municipal & Municipality $^{\mathrm{a}}$ \\
Fraction of irrigated area per crop & IBGE (2006) Censo Agropecuário & Municipality $^{\mathrm{a}}$ \\
\hline
\end{tabular}

Note: ${ }^{a}$ Brazil is administratively divided into 5565 municipalities; ${ }^{\mathrm{b}}$ for hydrological analyses, Brazil is subdivided into 166842 catchments.

et al. (1998). Reference evapotranspiration $\left(\mathrm{ET}_{\mathrm{o}}\right)\left(\mathrm{mm} \mathrm{d}^{-1}\right)$ was derived as

$\mathrm{ET}_{\mathrm{o}}=\frac{0.408 \Delta\left(R_{\mathrm{n}}-G\right)+\gamma \frac{900}{T+273} u_{2}\left(e_{\mathrm{s}}-e_{\mathrm{a}}\right)}{\Delta+\gamma\left(1+0.34 u_{2}\right)}$,

with net radiation $R_{\mathrm{n}}\left(\mathrm{MJ} \mathrm{m}^{-2} \mathrm{~d}^{-1}\right)$, soil heat flux density $G\left(\mathrm{MJ} \mathrm{m}^{-2} \mathrm{~d}^{-1}\right)$, air temperature $T$ at $2 \mathrm{~m}$ height $\left({ }^{\circ} \mathrm{C}\right)$, wind speed at $2 \mathrm{~m}$ height $u_{2}\left(\mathrm{~m} \mathrm{~s}^{-1}\right)$, saturated vapour pressure $e_{\mathrm{s}}$ $(\mathrm{kPa})$, actual vapour pressure $e_{\mathrm{a}}(\mathrm{kPa})$, slope of the vapour pressure curve $\Delta\left(\mathrm{kPa}^{\circ} \mathrm{C}^{-1}\right)$ and the psychrometric constant $\gamma\left(\mathrm{kPa}^{\circ} \mathrm{C}^{-1}\right) . \mathrm{ET}_{\mathrm{o}}$ is adapted to specific field crops by a crop coefficient $\left(K_{\mathrm{c}}\right)$, which varies over time and is adjusted to field conditions by a water stress coefficient $\left(K_{\mathrm{S}}\right)$ resulting in $\mathrm{ET}_{\text {act }}\left(\mathrm{mm} \mathrm{d}^{-1}\right)$ according to

$\mathrm{ET}_{\mathrm{act}}=\mathrm{ET}_{\mathrm{o}} \times K_{\mathrm{c}} \times K_{\mathrm{s}}$,

where $K_{\mathrm{c}}$ and $K_{\mathrm{s}}$ are dimensionless values. $K_{\mathrm{c}}$ reflects canopy development and changes over the course of the growing period, as measured by the number of days after sowing (DAS). The growing period was divided into the four periods, the initial period $\left(L_{\text {ini }}\right)$, growth period $\left(L_{\mathrm{dev}}\right)$, mid period $\left(L_{\text {mid }}\right)$ and late period $\left(L_{\text {end }}\right)$. A crop coefficient is related to three of the periods: $K_{\mathrm{c}, \text { ini }}, K_{\mathrm{c} \text {, mid }}$ and $K_{\mathrm{c} \text {,end. The }}$ crop coefficient of $L_{\mathrm{dev}}$ was interpolated in relation to the respective DAS and the values of $L_{\text {ini }}$ and $L_{\text {mid }}$.

The water stress coefficient $K_{\mathrm{S}}$ was derived on the basis of a simple water balance approach from the total available soil water (TAW), the actual root zone depletion $\left(D_{\mathrm{r}}\right)$ and a cropspecific water extraction coefficient $(p)(-)$ following Allen et al. (1998).

$K_{\mathrm{s}}=\frac{\mathrm{TAW}-D_{\mathrm{r}}}{(1-p) \mathrm{TAW}}$,

with the TAW and $D_{\mathrm{r}}$ in millimetres. TAW was derived from the wilting point, field capacity and the actual rooting depth $\left(Z_{\mathrm{r}}\right)$ according to Allen et al. (1998).

$\mathrm{TAW}=1000\left(\theta_{\mathrm{FC}}-\theta_{\mathrm{WP}}\right) z_{\mathrm{r}}$,

with the water content at field capacity $\left(\theta_{\mathrm{FC}}\right)$ and wilting point $\left(\theta_{\mathrm{WP}}\right)$ in $\mathrm{m}^{3} \mathrm{~m}^{-3}$ and the rooting depth $z_{\mathrm{r}}$ in metres.
The daily soil water depletion $D_{\mathrm{r}}(\mathrm{mm})$ at day $i$ was derived for soil layer $r$ from the water balance components.

$D_{\mathrm{r}, i}=D_{\mathrm{r}, i-1}-P_{\mathrm{eff}, i}-\operatorname{Irr}_{i}-\mathrm{CR}_{i}+\mathrm{ET}_{\mathrm{act}, i}+\mathrm{DP}_{i}$,

with daily effective precipitation $\left(P_{\text {eff }}\right)$, irrigation (Irr), capillary rise (CR) and deep percolation DP in millimetres. In order to account for the case $f=1$ (full irrigation), the daily irrigation depth Irr was calculated to fill up the soil water compartment to field capacity when the critical depletion was reached, i.e. any water stress is avoided. This approach reflects full irrigation practices. $P_{\text {eff }}$ was computed as $P-\mathrm{RO}$, where precipitation $P$ is taken from the meteorological input data and surface runoff RO was estimated on the basis of the curve number method according to Bosznay (1989), while CR was neglected.

\subsection{Blue-water scarcity}

\subsubsection{Calculation of current and potential blue-water consumption}

The expansion area, i.e. the rain-fed areas to be converted to irrigated land, was assessed considering and contrasting water consumption and water availability. The potential bluewater consumption for the full expansion of irrigation was calculated based on the irrigation required of all rain-fed areas. Blue-water consumption was derived for two scenarios. First, for the irrigated areas in 2012, which is subsequently denoted as the reference scenario. Second, for an expansion scenario under the assumption that all rain-fed areas are irrigated.

Knowing the potential consumption, the expansion of irrigated areas was then assessed with respect to the available blue-water resources. Water available for expansion was determined by subtracting the available blue water from the water consumption under the reference scenario (actually irrigated areas). The remainder is available to expand irrigation to rain-fed areas.

For each municipality the allocation of expansion of the irrigated area for the crops was assumed to be proportional to the ratio of the crops grown in the reference case. If the 
volume of available blue water is insufficient to meet the reference blue-water consumption of formerly rain-fed areas, the expansion areas for each crop are reduced proportionally to the cropping fractions in the municipality.

\subsubsection{Blue-water availability}

Following Flach et al. (2016), the availability of blue water was taken from the national Brazilian water resources inventory (ANA, 2016). There, $Q_{95}$, i.e. the river flow that is equalled or exceeded $95 \%$ of the time and increased by regulated flow from reservoirs, is taken as an indicator of physical availability of water. In essence, $Q_{95}$ is a measure for discharge in the low-flow season, thereby including regulated flows. Note that ANA provides the $Q_{95}$ values as averages over the time period 2008 to 2016. The production year 2012 studied here is at the centre of this average.

\subsubsection{Scarcity levels}

The ratio of gross water withdrawal to physical water availability is often called the withdrawal-to-availability ratio (Vanham et al., 2018) and is used as an indicator of water scarcity. Using the $Q_{95}$ indicator for water availability, Brazilian water authorities consider the appropriateness of the water withdrawal, as a fraction of water availability (i.e. scarcity levels), to be acceptable when it remains below $5 \%$, comfortable between $5 \%$ and $10 \%$, worrying between $10 \%$ and $20 \%$, critical between $20 \%$ and $40 \%$, and very critical above $40 \%$ (ANA, 2015). This classification is inspired by threshold values for water exploitation suggested by Raskin et al. (1997) and also used by the United Nations (UN, 1997).

In this paper, net water withdrawal (or blue-water consumption) rather than gross water withdrawal is compared to water availability, often termed the consumptionto-availability ratio (Vanham et al., 2018). Therefore, the scarcity levels described above were adjusted to reflect that withdrawals also include non-consumptive losses at the field scale and losses during transport of water to the field, which are not considered when calculating blue-water consumption. To account for this, a factor of 2 was applied, which is a central estimate of the ratio between withdrawal and consumptive blue-water use reported in Wriedt et al. (2009). The resulting scarcity levels represent the same classes of water scarcity from acceptable to very critical, but they are adapted to the threshold values of $2.5 \%, 5 \%, 10 \%$ and $20 \%$.

Using these thresholds for consumptive blue-water use, blue-water scarcity was analysed both for the reference situation and for a complete expansion of irrigation on the rainfed cropping area. Note that in the case of expansion of irrigation on the rain-fed cropping areas, the approach applied here does not account for dynamic changes in regional water availability due to increased upstream water consumption and hence an altered water availability downstream. The re- sults provided here summarise the scarcity assessment with respect to the pre-defined scarcity levels.

\subsection{Calculation of the extent of sustainable irrigation areas}

The sustainable expansion of irrigated areas on rain-fed cropping areas was assessed through the water consumptionto-availability ratio. Three management strategies are presented by limiting the available water under the assumption of scarcity levels acceptable, moderate and worrying. Each management strategy has been mapped spatially for reference and expansion scenarios. The volume of water available for consumptive blue-water use in irrigation was calculated at the level of municipalities for the different threshold levels of water scarcity. If this volume of blue water exceeds the consumptive blue-water requirement in the reference situation, the excess volume was allocated to irrigation expansion. For the irrigation expansion scenario the growing areas of the crops considered have been upscaled using the proportion of crops grown in the reference scenario. The overall extent of the expansion is chosen to either use all of the excess volume of blue water assumed to be available or to use all of the rain-fed cropping area. If the volume of available blue water (depending on the threshold for the scarcity level chosen) is insufficient to meet the reference blue-water requirement, the irrigated areas for each crop were reduced proportionally to achieve the chosen level of scarcity. Viable expansions at the municipal level were aggregated to regions for each of the threshold levels of water scarcity.

\section{Results}

\subsection{Spatial explicit modelling using SPARE:WATER}

\subsubsection{Crop water balance modelling}

The crop water balance components show significant differences between crops, partly due to differences in cropping locations within Brazil, different growing seasons, and between rain-fed and irrigated production systems (see Table 2). Average $\mathrm{ET}_{\mathrm{act}}$ values vary between $154 \mathrm{~mm}$ (Vigna spp., 3rd; Phaseolus spp.) and $925 \mathrm{~mm}$ (sugarcane) on rainfed areas. $\mathrm{ET}_{\mathrm{act}}$ is consistently higher on irrigated areas with average values between $260 \mathrm{~mm}$ (Vigna spp., 3rd; Phaseolus spp.), i.e. $69 \%$ higher than rain-fed areas and $1508 \mathrm{~mm}$ (sugarcane), i.e. $63 \%$ higher than rain-fed areas. Effective precip-

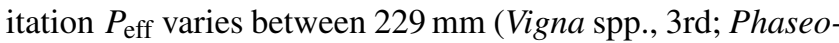
lus spp.) and $1574 \mathrm{~mm}$ (sugarcane), with high values relating to crops with comparably long growing periods. Crops with high IRR values are wheat $(291 \mathrm{~mm})$ and particularly sugarcane $(644 \mathrm{~mm})$, mainly due to the growing periods extending into the dry seasons. Another important fact is that even if effective rainfall could often cover potential ET in total, the rainfall was not available at the time of high crop water 
demands and could not be stored by the soil in a sufficient quantity, making it unavailable to the crop. Thus, irrigation is often required even if total rainfall is enough.

In Table 3 the results for $\mathrm{ET}_{\text {act }}, P_{\text {eff }}$, IRR, cropping area, and green- and blue-water consumption are summarised for the Cerrado region, one of the main areas of agricultural development and a biodiversity hotspot. $\mathrm{ET}_{\text {act }}$ is below the Brazilian average values in the cases of cotton $(6 \%)$, wheat (47\%) and sugarcane (14\%), as well as for beans (Vigna spp. and Phaseolus spp., 3rd) for the third sowing date (51\%). Other crops show an $\mathrm{ET}_{\text {act }}$ that is higher by $4 \%$ to $14 \%$. $P_{\text {eff }}$ is lower in the Cerrado for all crops by $7 \%$ to $65 \%$. A slightly higher $\mathrm{ET}_{\text {act }}$ (by $1 \%$ to $6 \%$ ) is estimated for irrigated production in the Cerrado region for all crops when compared to the average of Brazil. The irrigation depths in the Cerrado are found to exceed the Brazilian averages, e.g. $+17 \%$ for cotton, $+20 \%$ for sugarcane, $+23 \%$ for the second sowing date for corn, $+30 \%$ for wheat, as well as $+7 \%$ and $+26 \%$ for the second and third sowing date of bean.

\subsubsection{Green- and blue-water consumption}

The total water consumption of the nine crops considered in this study is $285.5 \mathrm{~km}^{3}$ in the production year 2012 (Table 2). Green water is dominating with $95 \%$ of the total consumption. The majority (91\%) of the green-water consumption was consumed on rain-fed areas (53.8 Mha, including double and triple cropping) and only a minor fraction on irrigated areas (4.9 Mha).

The spatial distribution of the total, green- and blue-water consumption in crop production is shown in Fig. 1. The North Region of Brazil (the states of Acre, Amapá, Amazonas, Pará, Rondônia, Roraima and Tocantins) consumes only a minor fraction $(3 \%)$ of the national total volume. Agriculture is not intensive in this area and many regions are not cultivated because of climate conditions, the nonsuitability of soils and nature protection in the Amazonas region. The highest percentage of green-water consumption is found in the Centre-West (34\%) (the states of Goiás, Mato Grosso, Mato Grosso do Sul and Distrito Federal) and the highest percentage of blue-water consumption occurs the Northeast (the states of Alagoas, Bahia, Ceará, Maranhão, Paraíba, Pernambuco, Piauí, Rio Grande do Norte and Sergipe) and the Southeast (the states of Espírito Santo, Minas Gerais, Rio de Janeiro and São Paulo) with $31 \%$ and $39 \%$, respectively. Water consumption displays a distinct change in pattern from west to east (western areas: rain fed; eastern areas: irrigated). The majority of green water is consumed by soybean, sugarcane and corn with $37.8 \%, 28.6 \%$ and $21.5 \%$, respectively. Regarding blue water, sugarcane $\left(10.0 \mathrm{~km}^{3} \mathrm{a}^{-1}\right)$, rice $\left(2.3 \mathrm{~km}^{3} \mathrm{a}^{-1}\right)$, corn $\left(1.1 \mathrm{~km}^{3} \mathrm{a}^{-1}\right)$ and soybean $\left(0.9 \mathrm{~km}^{3} \mathrm{a}^{-1}\right)$ consume with $92.9 \%$ the highest fraction.

The Cerrado (Fig. 1, delimited by black line) is one of the most sensitive landscapes and is comprised of about half of both irrigated and rain-fed areas in Brazil with $46 \%$ and $47 \%$. The large extent of agricultural areas comes with a high green- and blue-water consumption of 132 and $5.7 \mathrm{~km}^{3} \mathrm{a}^{-1}$ (together $48 \%$ of the total across Brazil). The average field scale water consumption $\left(\mathrm{mm} \mathrm{a}^{-1}\right)$ shows a higher $(\sim 5 \%)$ green- and lower $(\sim 19 \%)$ blue-water consumption when compared to Brazil's average.

\subsection{Blue-water scarcity}

Blue-water availability and scarcity are shown in Fig. 2. The available water flows have been classified according to seven groups between $80 \mathrm{~mm} \mathrm{a}^{-1}$ and greater than $2560 \mathrm{~mm} \mathrm{a}^{-1}$ related to water scarcity levels of $2.5 \%, 5 \%, 10 \%$ and $20 \%$. The highest values are located in the North near the Amazonas River with a median $Q_{95}$ of $765 \mathrm{~mm} \mathrm{a}^{-1}$. $Q_{95}$ decreases in particular in the eastern areas with 26 and $197 \mathrm{~mm} \mathrm{a}^{-1}$ in the Northeast and Southeast. The Cerrado area has also comparable low values with a median of $177 \mathrm{~mm} \mathrm{a}^{-1}$.

The blue-water scarcity for current irrigated areas (Fig. 2b) shows a specific regional pattern. Most of the agricultural areas are classified as to either meet acceptable (35\%) or very critical $(38 \%)$ water scarcity. In the Cerrado region $44 \%$ of the area is in the category acceptable, and $23 \%$ of the area is in the category very critical. The highest quantity of very critical catchments is located in the Northeast and Southeast with $64 \%$ and $49 \%$, respectively. The largest percentages of areas in the category acceptable lie in the North $(94 \%)$ and Centre-West (65\%).

The situation would change significantly when also rainfed areas are irrigated as shown in Fig. 2c, with an increase of the category very critical with $48 \%$ and a lower fraction in the class acceptable with $24 \%$. A similar change can be observed for the Cerrado region with $38 \%$ of very critical catchments. The catchments with a higher scarcity are located in the southern and eastern areas of Brazil, as well as in the eastern part of the Cerrado itself.

The higher scarcity for the potentially irrigated area can be caused by two additive impacts, i.e. a low $Q_{95}$ and a high additional water demand. Two regions stand out regarding water availability: the northern and northeastern parts with comparably high availability and the eastern regions with low availability. The other parts of the country show mixed water availability, with regions of higher and lower values (Fig. 2a). The maximum and minimum quantities of water availability and consumption are heavily skewed to the blue-water scarcity classes acceptable and very critical. For example, water scarcity in most catchments is classified as acceptable or very critical for current irrigated areas (Fig. 3a). In this case, the class acceptable is dominated by agriculture fields with an average blue-water consumption below $80 \mathrm{~mm} \mathrm{a}^{-1}$. The catchments classified as very critical are dominated by agriculture fields consuming more than $640 \mathrm{~mm} \mathrm{a}^{-1}$. The highest water availability (often larger than $1280 \mathrm{~mm} \mathrm{a}^{-1}$ ) 
Table 2. Crop water balance and water consumption of rain-fed and irrigated crops in Brazil for the production year 2012. "1st", "2nd" and "3rd" are the first, second and third planting dates for successive multiple cropping practices within one growing season. Crop development stages are provided in Table A1, and planting and harvesting dates are provided in Table A2.

\begin{tabular}{|c|c|c|c|c|c|c|c|}
\hline & Crop & $\begin{array}{l}\mathrm{ET}_{\mathrm{act}} \\
(\mathrm{mm})\end{array}$ & $\begin{array}{r}P_{\text {eff }} \\
(\mathrm{mm})\end{array}$ & $\begin{array}{r}\text { IRR } \\
(\mathrm{mm})\end{array}$ & $\begin{array}{r}\text { Cropping area } \\
\text { (ha) }\end{array}$ & $\begin{array}{l}\text { Green water } \\
\left(\mathrm{km}^{3} \mathrm{a}^{-1}\right)\end{array}$ & $\begin{array}{c}\text { Blue water } \\
\left(\mathrm{km}^{3} \mathrm{a}^{-1}\right)\end{array}$ \\
\hline \multirow[t]{15}{*}{ Rain fed } & Vigna spp., 1st & 244 & 648 & & 6097 & 0.010 & \\
\hline & Phaseolus spp., 1st & 244 & 648 & & 799232 & 1.824 & \\
\hline & Cotton & 447 & 954 & & 1315585 & 5.643 & \\
\hline & Cassava & 443 & 1114 & & 1491520 & 5.864 & \\
\hline & Corn, 1st & 438 & 975 & & 6613805 & 31.076 & \\
\hline & Soybean & 355 & 823 & & 23692402 & 92.524 & \\
\hline & Vigna spp., 2nd & 214 & 389 & & 6097 & 0.009 & \\
\hline & Phaseolus spp., 2nd & 214 & 389 & & 799232 & 1.593 & \\
\hline & Corn, 2nd & 328 & 477 & & 6613805 & 21.534 & \\
\hline & Wheat & 310 & 406 & & 1827587 & 6.066 & \\
\hline & Vigna spp., 3rd & 154 & 229 & & 6097 & 0.008 & \\
\hline & Phaseolus spp., 3rd & 154 & 229 & & 799232 & 0.913 & \\
\hline & Rice & 462 & 956 & & 1652877 & 7.754 & \\
\hline & Sugarcane & 925 & 1574 & & 8143700 & 70.145 & \\
\hline & Subtotal & & & & 53767270 & 244.963 & \\
\hline \multirow[t]{16}{*}{ Irrigated } & Vigna spp., 1st & 299 & 648 & 138 & 770 & 0.001 & 0.002 \\
\hline & Phaseolus spp., 1st & 299 & 648 & 138 & 99053 & 0.218 & 0.124 \\
\hline & Cotton & 592 & 954 & 216 & 66322 & 0.248 & 0.175 \\
\hline & Cassava & 565 & 1114 & 183 & 189305 & 0.684 & 0.489 \\
\hline & Corn, 1st & 532 & 975 & 206 & 438283 & 2.041 & 0.459 \\
\hline & Soybean & 432 & 823 & 180 & 1176186 & 4.630 & 0.875 \\
\hline & Vigna spp., 2nd & 276 & 389 & 106 & 770 & 0.001 & 0.001 \\
\hline & Phaseolus spp., 2nd & 276 & 389 & 106 & 99053 & 0.174 & 0.115 \\
\hline & Corn, 2nd & 494 & 477 & 245 & 438283 & 1.272 & 0.619 \\
\hline & Wheat & 514 & 406 & 291 & 58916 & 0.193 & 0.036 \\
\hline & Vigna spp., 3rd & 260 & 229 & 159 & 770 & 0.001 & 0.001 \\
\hline & Phaseolus spp., 3rd & 260 & 229 & 159 & 99053 & 0.111 & 0.143 \\
\hline & Rice & 623 & 956 & 236 & 753691 & 3.220 & 2.342 \\
\hline & Sugarcane & 1508 & 1574 & 644 & 1507080 & 12.386 & 9.979 \\
\hline & Subtotal & & & & 4927531 & 25.181 & 15.360 \\
\hline & Total & & & & 58694801 & 270.145 & 15.360 \\
\hline
\end{tabular}

is attributed to catchments classified as acceptable (Fig. 3b). Catchments with a lower water availability $\left(<160 \mathrm{~mm} \mathrm{a}^{-1}\right)$ are mostly characterised as very critical. This distribution is similar for current (Fig. 3a, b) and rain-fed (Fig. 3c, d), i.e. potentially irrigated, areas.

\subsection{Extent of sustainable irrigation areas}

Three scarcity levels were analysed in detail, namely acceptable, comfortable and worrying (Table 4). Current irrigated areas add up to $4.29 \mathrm{Mha}$ without accounting for multiple cropping. Only 1.99 Mha of this area, i.e. $46.4 \%$, should be irrigated when an acceptable blue-water scarcity level is to be realised. The areas that do not meet the threshold of acceptable water scarcity $(1.57 \mathrm{Mha})$ lie in catchments that are currently classified as very critical. Allowing higher scarcity levels (comfortable or worrying) would allow 2.38 and $2.78 \mathrm{Mha}$ of the current irrigation areas to remain irrigated. Note that worrying water scarcity is the highest level of scarcity that avoids critical conditions. Expanding irrigation in order to irrigate all rain-fed fields would result in an additional irrigated area of $45.56 \mathrm{Mha}$ (i.e. the rain-fed area without the multiple cropping areas listed in Table 1), with 22.00 Mha of the additional area in catchments with very critical and 4.02 Mha with critical water scarcity. Expansion of the irrigation area by $16.68 \mathrm{Mha}(36.6 \%), 20.68 \mathrm{Mha}$ $(45.4 \%)$ or 24.89 Mha $(54.6 \%)$ would be achievable for the blue-water scarcity levels acceptable, comfortable and worrying.

The extent of sustainable irrigation areas is shown in Fig. 4 in classes ranging from $20 \%$ to $100 \%$ for each catchment. The classes represent the percentage change needed to reach 
Table 3. Crop water balance and water consumption of rain-fed and irrigated crops in the Cerrado region of Brazil for the production year 2012. "1st", "2nd" and "3rd" are the first, second and third planting dates for successive multiple cropping practices within one growing season. Crop development stages are provided in Table A1, and planting and harvesting dates are provided in Table A2.

\begin{tabular}{|c|c|c|c|c|c|c|c|}
\hline & Crop & $\begin{array}{l}\mathrm{ET}_{\mathrm{act}} \\
(\mathrm{mm})\end{array}$ & $\begin{array}{r}P_{\text {eff }} \\
(\mathrm{mm})\end{array}$ & $\begin{array}{r}\text { IRR } \\
(\mathrm{mm})\end{array}$ & $\begin{array}{r}\text { Cropping area } \\
\text { (ha) }\end{array}$ & $\begin{array}{l}\text { Green water } \\
\left(\mathrm{km}^{3} \mathrm{a}^{-1}\right)\end{array}$ & $\begin{array}{c}\text { Blue water } \\
\left(\mathrm{km}^{3} \mathrm{a}^{-1}\right)\end{array}$ \\
\hline \multirow[t]{15}{*}{ Rain fed } & Vigna spp., 1st & 285 & 607 & & 534 & 0.001 & \\
\hline & Phaseolus spp., 1st & 285 & 607 & & 240816 & 0.681 & \\
\hline & Cotton & 419 & 700 & & 1232061 & 5.226 & \\
\hline & Cassava & 498 & 997 & & 228505 & 0.980 & \\
\hline & Corn, 1st & 477 & 793 & & 2854404 & 14.000 & \\
\hline & Soybean & 402 & 724 & & 12081675 & 49.685 & \\
\hline & Vigna spp., 2nd & 204 & 265 & & 534 & 0.001 & \\
\hline & Phaseolus spp., 2nd & 204 & 265 & & 240816 & 0.493 & \\
\hline & Corn, 2nd & 274 & 273 & & 2854404 & 9.456 & \\
\hline & Wheat & 211 & 144 & & 95376 & 0.270 & \\
\hline & Vigna spp., 3rd & 102 & 82 & & 534 & 0.000 & \\
\hline & Phaseolus spp., 3rd & 102 & 82 & & 240816 & 0.249 & \\
\hline & Rice & 483 & 816 & & 533050 & 2.560 & \\
\hline & Sugarcane & 813 & 1179 & & 4136773 & 35.580 & \\
\hline & & & & & 24740298 & 119.182 & \\
\hline \multirow[t]{16}{*}{ Irrigated } & Vigna spp., 1st & 312 & 607 & 553 & 95 & 0.000 & 0.000 \\
\hline & Phaseolus spp., 1st & 312 & 607 & 553 & 39378 & 0.110 & 0.016 \\
\hline & Cotton & 624 & 700 & 2606 & 60942 & 0.231 & 0.156 \\
\hline & Cassava & 591 & 997 & 1175 & 29508 & 0.135 & 0.047 \\
\hline & Corn, 1st & 565 & 793 & 1349 & 237558 & 1.164 & 0.167 \\
\hline & Soybean & 454 & 724 & 892 & 759294 & 3.145 & 0.216 \\
\hline & Vigna spp., 2nd & 285 & 265 & 1149 & 95 & 0.000 & 0.000 \\
\hline & Phaseolus spp., 2nd & 285 & 265 & 1149 & 39378 & 0.074 & 0.035 \\
\hline & Corn, 2nd & 507 & 273 & 3170 & 237558 & 0.703 & 0.359 \\
\hline & Wheat & 530 & 144 & 4165 & 13109 & 0.033 & 0.020 \\
\hline & Vigna spp., 3rd & 268 & 82 & 2149 & 95 & 0.000 & 0.000 \\
\hline & Phaseolus spp., 3rd & 268 & 82 & 2149 & 39378 & 0.041 & 0.056 \\
\hline & Rice & 627 & 816 & 1703 & 72836 & 0.389 & 0.050 \\
\hline & Sugarcane & 1577 & 1179 & 8040 & 783690 & 6.575 & 4.530 \\
\hline & & & & & 2312915 & 12.60 & 5.65 \\
\hline & Total & & & & 27053214 & 131.78 & 5.65 \\
\hline
\end{tabular}

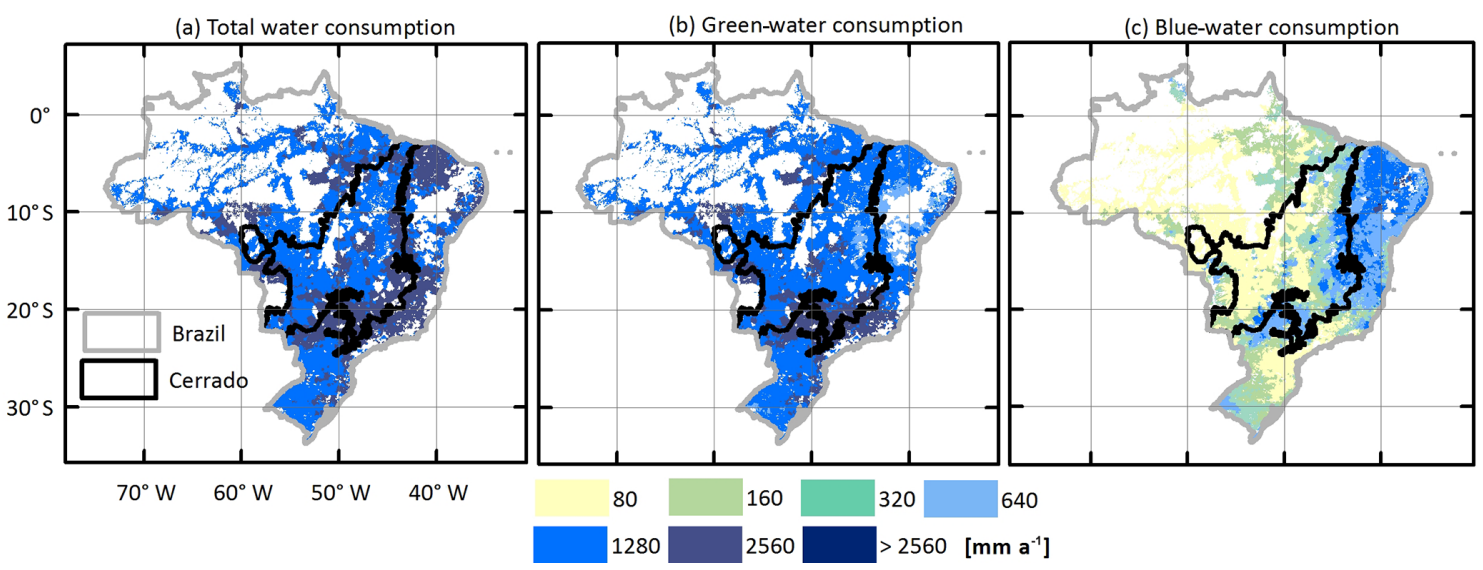

Figure 1. Spatial distribution of the water consumption in crop production in Brazil for the crops considered in this study: (a) total, (b) greenand (c) blue-water consumption. The black line delimits the Cerrado region. 


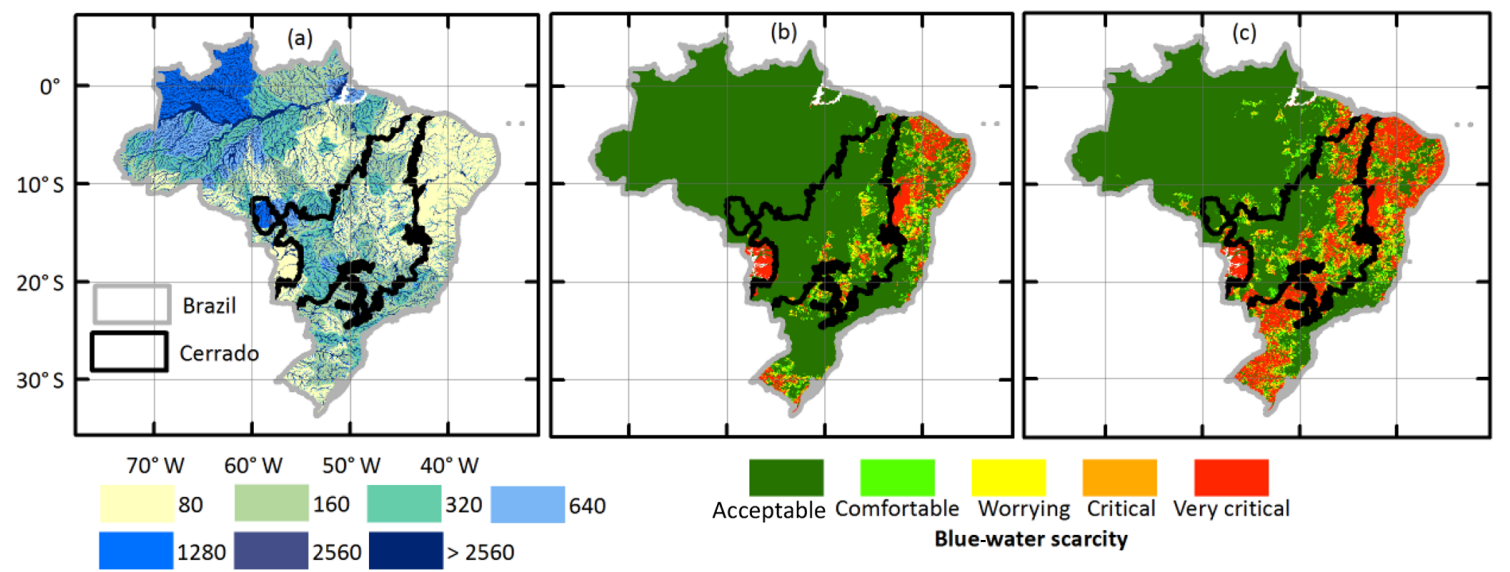

Figure 2. Water scarcity of 166844 catchments across Brazil. (a) Annual average water availability $Q_{95}$. (b) Blue-water scarcity classification of irrigated areas. (c) Blue-water scarcity classification of rain-fed areas when irrigated. The black line delimits the Cerrado region.

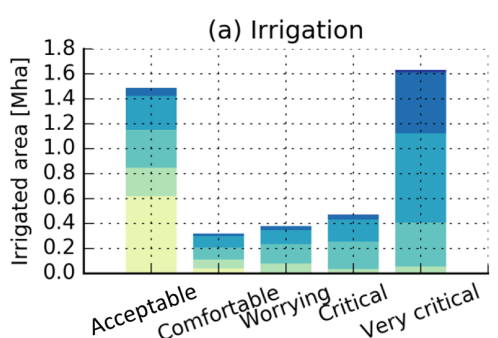

(c) Potential irrigation

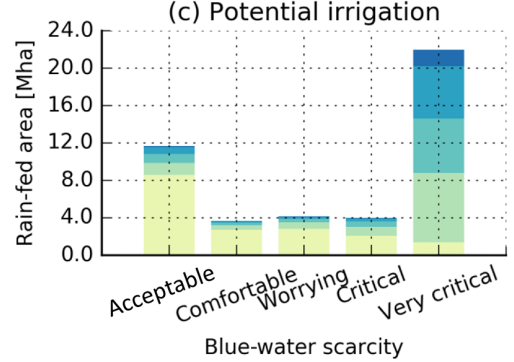

(b) $\mathrm{Q}_{95}$

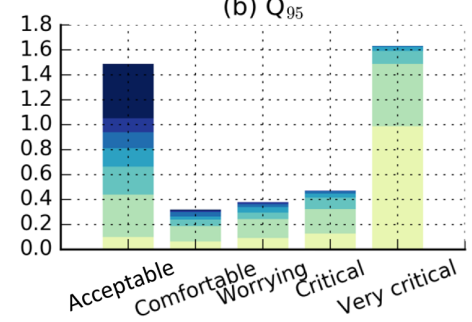

(d) $\mathbf{Q}_{95}$

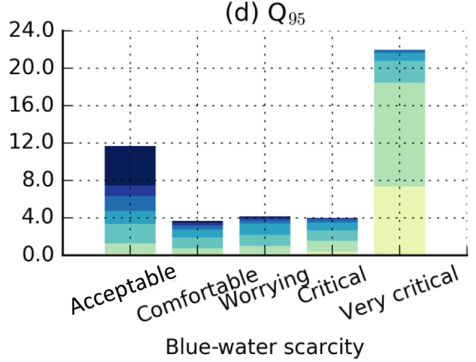

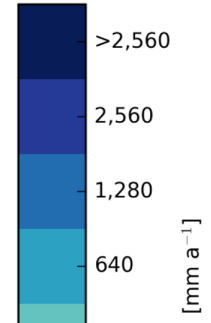

320

160

80

Figure 3. Classification of blue-water consumption (a, c) and blue-water availability (b, d) for irrigated areas (a, b; 4.29 Mha) and potential irrigated areas (c, d; 45.56 Mha) according to blue-water scarcity levels.

a certain level of water scarcity. For example, a countrywide acceptable scarcity level for the reference scenario (Fig. 4a) is only achievable if the currently irrigated areas in large parts of eastern Brazil as well as in the south and west are reduced to $20 \%$ of the actual extent. The sustainable irrigation area for scarcity levels comfortable and worrying are shown in Fig. $4 \mathrm{~b}$ and $\mathrm{c}$, respectively. The highest reductions are required in the Northeast, the eastern part of the Cerrado and in southern regions of Brazil. A similar calculation has been conducted for potentially irrigated areas (Fig. 4d-f). Only a modest fraction of the currently rain-fed areas should be irrigated, while keeping blue-water scarcity at acceptable, comfortable or worrying levels, as shown in Fig. 4d, e and f, with expansions mainly feasible in the Southeast, the western part of the Cerrado and in the Amazon basin.

\section{Discussion}

In the present study the biophysical boundaries of the said strategy have been specified in a quantitative manner by comparing the potential water demand to fully cover the water demand of rain-fed areas by irrigation with the available river flows. The underlying environmental and agronomic data were carefully selected to account for the high spatial variation of hydrological conditions across Brazil. A few choices and the resulting implications require further attention.

With respect to the choice of a water availability indicator, $Q_{95}$ has been selected in order to provide a conservative water availability scenario. This is important due to the high variability of hydrological conditions in Brazil and to account for dry periods over time. Moreover, choosing 
Table 4. Extent of current and potential irrigated areas under various scarcity levels for the reference and expansion scenario.

\begin{tabular}{|c|c|c|c|c|c|c|c|c|}
\hline & \multicolumn{4}{|c|}{$\begin{array}{c}\text { Reference scenario } \\
\text { Irrigated areas - target blue-water scarcity }\end{array}$} & \multicolumn{4}{|c|}{$\begin{array}{c}\text { Expansion scenario } \\
\text { Potentially irrigated areas - target blue- } \\
\text { water scarcity }\end{array}$} \\
\hline & Without & Acceptable & Comfortable & Worrying & Without & Acceptable & Comfortable & Worrying \\
\hline & \multicolumn{8}{|c|}{ Mha } \\
\hline Acceptable & 1.49 & 1.49 & 1.49 & 1.49 & 11.69 & 11.69 & 11.69 & 11.69 \\
\hline Comfortable & 0.32 & 0.23 & 0.32 & 0.32 & 3.71 & 2.62 & 3.71 & 3.71 \\
\hline Worrying & 0.38 & 0.13 & 0.27 & 0.38 & 4.14 & 1.35 & 2.89 & 4.14 \\
\hline Critical & 0.47 & 0.08 & 0.17 & 0.34 & 4.02 & 0.58 & 1.32 & 2.87 \\
\hline Very critical & 1.63 & 0.06 & 0.13 & 0.25 & 22.00 & 0.44 & 1.07 & 2.5 \\
\hline Total & 4.29 & 1.99 & 2.38 & 2.78 & 45.56 & 16.68 & 20.68 & 24.89 \\
\hline
\end{tabular}
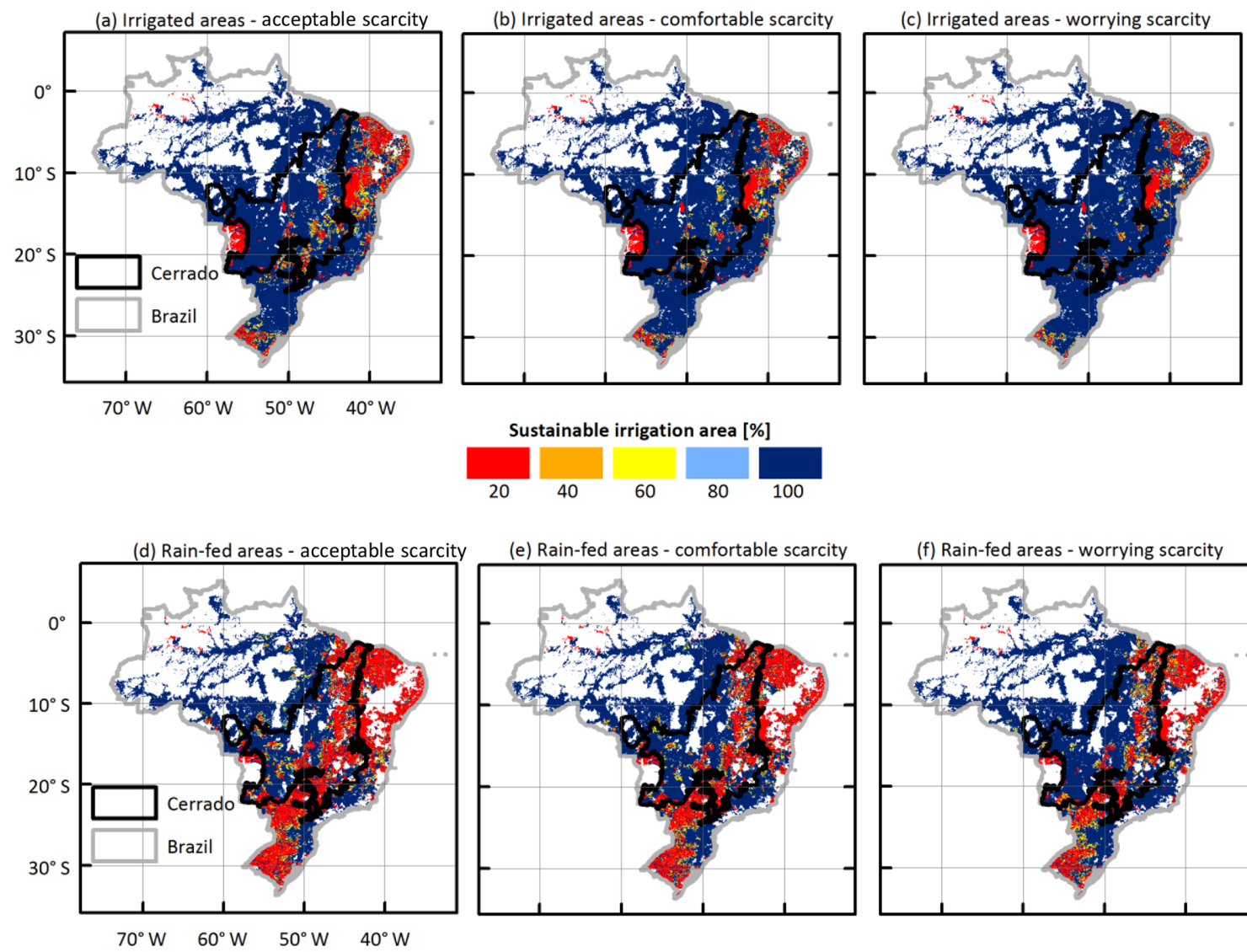

(e) Rain-fed areas - comfortable scarcity
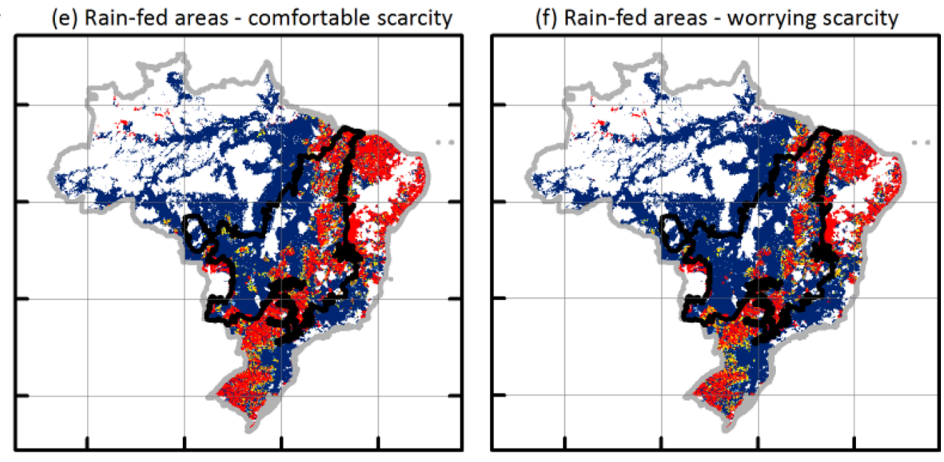

Figure 4. Fraction of current irrigated areas $(\mathbf{a}, \mathbf{b}, \mathbf{c})$ and potentially irrigated areas $(\mathbf{d}, \mathbf{e}, \mathbf{f})$ which can be sustainably irrigated according to a target blue-water scarcity level of acceptable $(\mathbf{a}, \mathbf{d})$, comfortable $(\mathbf{b}, \mathbf{e})$ and worrying $(\mathbf{c}, \mathbf{f})$.

$Q_{95}$ complies with the indices utilised by the Brazilian water agency ANA and decision makers.

The selection of crop-specific parameter sets was an important aspect in the design of such a study. Crop coefficients and the length of growing seasons of the individual crops studied here have been assembled from a well-recognised source (Allen et al., 1998; i.e. parameters implemented in the Food and Agriculture Organization of the United Nations (FAO) CROPWAT model), a Brazilian study (Hernandes et al., 2014) and regional information for Brazil, as provided by Companhia Nacional de Abastecimento (Conab) (https: //www.conab.gov.br/, last access: 25 November 2019). We acknowledge that further spatial differentiation is desirable, should reliable data be available. We have chosen the proce- 
dures put forth by Allen et al. (1998), as their high level of robustness, transferability and repeatability have been shown (Pereira et al., 2015). Moreover, in a large-scale irrigation requirement study for the Murray-Darling basin, Multsch et al. (2013) report that the choice of the potential evapotranspiration calculation method outweighs the role of the local refinement of crop coefficients. Lastly, planting dates are known to change based on the onset of the rainy season (Arvor et al., 2014), which is strong evidence for the use of a window of planting dates based on precipitation regimes different regions. To address this, the actual and region-specific crop calendars (Conab, 2015) were utilised for the determination of crop water requirements to account for varying conditions in different parts of Brazil.

The content of blue soil water and the blue-water fluxes could be further separated into blue water originating from irrigation water and blue water originating from capillary rise, as for example in Chukalla et al. (2015), to track which fractions of ET originate from rainwater, irrigation water and capillary rise, respectively.

An important aspect when assessing water scarcity caused by agricultural water consumption is return flows, e.g. due to evapotranspiration recycling (Berger et al., 2014) or water losses in irrigation systems (Pereira et al., 2002; Jägermeyr et al., 2015). We neglect evapotranspiration recycling effects in the present study, since great care has been taken to subdivide the study area into sub-catchments with sizes where this effect does not play a significant role. The calculated bluewater consumption represents net water requirements, which only includes evapotranspiration by crops and from soils.

Determination of water scarcity was carried out here using the consumption-to-availability ratio. Two aspects require further discussion: the effect of environmental flow requirements and of non-consumptive losses. Environmental flow requirements (EFR) were not included here. Considering EFR results in a reduction of blue-water availability (Boulay et al., 2018; Hoekstra et al., 2012), the water scarcity levels determined here would increase. It is challenging to determine the level of environmental flow requirements for a given region (Hoekstra et al., 2012). Such an analysis is beyond the scope of the current study. A broad range of methods is available in the literature (e.g. Abdi and Yasi, 2015; Hoekstra et al., 2012; Książek et al., 2019; Richter et al., 2012; Smakhtin et al., 2004; Tennant, 1976). In future work it is recommended to select an adequate method to determine EFR and to include such EFRs to carry out a detailed assessment of the impacts of different potential cropping systems on the water cycle, thereby including a quantification of land and water resource trade-offs in the context of agricultural intensification, as suggested by Lathuillière et al. (2018). Losses, e.g. at the field scale and during transport, were considered by adjusting the scarcity levels. The adjustment was based on the work by Wriedt et al. (2009), who estimated gross irrigation demands in the European Union and Switzerland to be 1.3-2.5 times higher than field require- ments, depending on the efficiency of transport and irrigation management. To consider these non-consumptive losses, the scarcity levels in the current study were adjusted from those originally used by ANA (2015) (acceptable below $5 \%$, comfortable between $5 \%$ and $10 \%$, worrying between $10 \%$ and $20 \%$, critical between $20 \%$ and $40 \%$, and very critical above $40 \%$ ) using a central factor of 2 . Applying the lower (1.3) or higher (2.5) bound found by Wriedt et al. (2009) would result in higher $(3.8 \%, 7.7 \%, 15.4 \%$ and $30.1 \%)$ and lower $(2 \%, 4 \%, 8 \%$ and $16 \%)$ scarcity thresholds, respectively, than those employed here using the factor of $2(2.5 \%, 5 \%$, $10 \%$ and $20 \%$ ).

It is critical to note that pumping river water for irrigation, as investigated here, likely has impacts on natural systems and should be carefully evaluated, thereby considering water management measures. In addition, the effect of land conversion requires attention. Recent studies show the potential effects of future land use and land cover change scenarios in the Amazonian region of Brazil on the hydrological regime in the region (Abe et al., 2018; Dos Santos et al., 2018). The results of the spatially explicit quantification regarding water resources of this study add information on several aspects as explained below.

\subsection{Expansion and intensification of irrigation areas}

The agricultural policy of Brazil has been investigated with a focus on water resources. By using a spatially explicit and process-oriented modelling approach, the extent of sustainable irrigation areas was quantified. Future policy will need to decide on the level of the expansion and intensification of agricultural areas. Others (Alkimim et al., 2015; Sparovek et al., 2015; Spera, 2017; Strassburg et al., 2014) made a strong case that agricultural expansion into currently uncultivated areas can be avoided through the efficient utilisation of currently cultivated areas, mainly those allocated to extensive grazing. The quantification of sustainable irrigation areas has shown that the use of irrigation as a large-scale intensification strategy is limited. On the one hand, even currently irrigated areas (reference scenario) must be reduced in order to achieve an acceptable scarcity level. Thus, intensification would be in some areas highly unfavourable and current mechanisms of water use monitoring and control need to be improved. On the other hand, some rain-fed areas (expansion scenario) may be irrigated in the future without resulting in higher scarcity due to adequate blue-water availability. Thus, this spatially explicit analysis can inform agricultural policymaking with regard to water resources management in order to implement likely agricultural expansion in the future in a sustainable manner. This in turn can be linked to the trade of agricultural commodities. For example, da Silva et al. (2016) determined that the Northeast Region of Brazil, with low water availability (see Fig. 2), shows a substantial import of agricultural commodities. 
Regarding intensification, employing state-of-the-art irrigation technology and the further development of such technology would be in line with an objective of Brazil's irrigation policy through Law 12,787 , i.e. to train human resources and foster the creation and transfer of technologies related to irrigation. Fachinelli and Pereira (2015) point out the potential yield increase through irrigation and hence an opportunity to reduce related land requirements for sugarcane expansion. Future work should assess the potential of the efficient use of water resources regarding irrigation technology to further refine the quantification of sustainable irrigation areas, including not only biophysical variables but also infrastructure availability (ANA, 2019) and socioeconomic conditions. Needless to say, in future work groundwater availability and water available in small dams previously used for cattle drinking water (Rodrigues et al., 2012) should be considered in addition to surface water availability, as was done in the current work.

\subsection{Protecting the Cerrado}

The Brazilian government has identified new areas for agricultural development in the northeastern part of the Cerrado, which became an agricultural frontier in the early 2000 s. How would such a policy impact water resources? To answer this question, some knowledge regarding the landscape level development must be provided. On 6 May 2015, Brazilian Decree 8447 officially committed government support for the agriculture and livestock development plan Plano de Desenvolvimento Agropecuário (PDA) do MATOPIBA for the "MATOPIBA" region, i.e. 337 municipalities that span the states of Maranhão (MA), Tocantins (TO), southern Piauí (PI) and western Bahia (BA) (Spera et al., 2016). It must be noted that around $90 \%$ of MATOPIBA lies within the Cerrado biome. Spera et al. (2016) point out that unlike most of the Cerrado, MATOPIBA does not have a history of large-scale cattle ranching. As a result, cropland expansion in MATOPIBA is advancing primarily through clearing native vegetation rather than by using previously cleared pasturelands. It has been pointed out by others that careful planning for the region should allow for large-scale agriculture to grow and contribute to rural economic development in a way that harmonises with other uses of the landscape and other economic development pathways (Dickie et al., 2016).

A further policy evaluation is feasible now that the bluewater scarcity levels as presented in the current study are available. Nearly the half of Brazil's irrigated and rain-fed area is located in the Cerrado area and requires a similar fraction for water consumption. Thus, policy strategies for Brazil regarding agricultural expansion will have a significant impact on that region, in particular on water resources. Currently, the scarcity levels of the area are mostly acceptable and comfortable, and most areas under worrying and critical scarcity lie outside of the Cerrado area. Irrigation of rain-fed areas would tremendously change this situation and increase blue-water scarcity to a worst-case situation. In order to maintain sustainability with respect to surface water resources, less than $20 \%$ of the rain-fed areas should be irrigated.

\subsection{Green-water management}

In addition to the spatial aspects regarding expansion, the temporal variability of water availability and consumption is crucial to support policymaking. The high evaporative deficit on rain-fed areas as shown by the crop water balance model deserves special attention. Although rainfall rates can potentially cover the crop ET in many regions, the plant available soil moisture is not sufficient to store and provide enough water, especially in lighter-textured soils (i.e. sandy or sandy loam). Additionally, a low infiltration capacity makes soils classified as clay or clay loam soils unable to store highintensity rainfall.

Measures focusing on managing green-water resources as proposed elsewhere (e.g. Multsch et al., 2016; Rockström et al., 2010; Rost et al., 2009) for agriculture systems worldwide can potentially improve the water holding capacity. While restricting water use of irrigated crops to green water may lead to substantial production losses (Siebert and Döll, 2010), improved irrigation practices can support the reduction of non-beneficial water consumption, without compromising yield levels (Jägermeyr et al., 2015). Different measures to improve green-water management have been evaluated by Jägermeyr et al. (2016) on the global scale showing that the kilocalories derived from agricultural production could be enhanced by $3 \%-14 \%$ by soil moisture conservation and by $7 \%-24 \%$ by water harvesting. In order to store the high surface runoff which occurs in Brazil's agricultural systems, in situ rainfall harvesting by conservation tillage and mulching may be helpful measures in order to improve agricultural productivity in a sustainable manner.

Based on the work shown here, specific scenarios can be evaluated, such as the cultivation of a second and/or third cropping cycle for selected crops, using water resources for bridging dry spells during the growing season only (supplemental irrigation) or utilisation of water resources to avoid late planting due to unfavourable climatic conditions. Thus, this study provides a basis to further investigate specific measures, thereby considering various agriculture management strategies in space and time.

\subsection{Water recycling}

Another important aspect of sustainable irrigation is the effect on the amount of water recycled to the atmosphere via evapotranspiration. Spera et al. (2016) find by the analysis of remote sensing data that the conversion of Cerrado vegetation into cropland resulted in changes in water recycling that show dependency on the cropping frequency, with double cropping behaving more akin to the natural system. Future 
investigations of this kind should include the additional effect of various irrigation strategies, combined with the effect of cropping frequency and area response to climate variability, whereby the importance of the latter has been highlighted by Cohn et al. (2016).

\section{Conclusions}

Based on the assessment of crop water consumption as fraction of water availability (in terms of $Q_{95}$ ) and classifying the results regarding water scarcity for Brazil, the following can be concluded:

- Avoiding critical water scarcity on currently irrigated land. In order to avoid critical water scarcity, irrigation must be discontinued on $54 \%$ of the area (2.3 Mha) for an acceptable water scarcity level, on $45 \%$ (1.9 Mha) for a comfortable water scarcity level and on $35 \%$ (1.5 Mha) for a worrying water scarcity level of 4.3 Mha of currently irrigated land (not considering multiple cropping).

- Avoiding critical water scarcity on currently rain-fed land. For $37 \%$ (16.7 Mha) of the currently 45.6 Mha rain-fed land the blue-water scarcity level would remain acceptable, for $45 \%$ (20.7 Mha) comfortable and $55 \%$ (24.9 Mha) worrying under irrigation (not considering multiple cropping).

- Expansion of agriculture into currently uncultivated areas. Given that there is potential for additional irrigation areas and taking into account estimates by FAO, which estimates that a cropping intensity of $120 \%$ can be achieved on irrigated land (http://www.fao.org/ nr/water/aquastat/countries_regions/BRA/, last access: 25 November 2019), production on currently cultivated land can overall be made more efficient through investment in irrigation infrastructure. This lends support to the statement made in other work that an expansion into currently uncultivated land is not required in order to increase agricultural productivity.

- Decision support for stakeholders and decision-makers. The results cover different water scarcity categories, which allows for a trade-off analysis among stakeholders and decision-makers as to which level of water scarcity and the related consequences are acceptable to reach a given goal.
- Global virtual water flows. The agricultural policy will affect local farmers as well as global markets, given the global dimension of Brazil's agriculture. Brazil is a country which imports blue-water resources and exports its green-water resources (Fader et al., 2011). The vast green-water exports have been attributed to soybean, which is strongly requested on the world market, in particular by China (Dalin et al., 2012), to sustain a human diet and livestock nutrition. A similar picture applies to sugarcane, since Brazil has a share of $30 \%$ of global production (Gerbens-Leenes and Hoekstra, 2012). An expansion of irrigated areas would therefore significantly alter global virtual water flows.

In studying possible expansion of irrigated areas, as encouraged by the Brazilian government under Law 12,787, this paper addresses the trade-off between the choice of the level of blue-water scarcity that is deemed acceptable and the feasible expansion of the irrigated area complying with that limitation. In addressing this issue, we restrict the analysis to irrigation expansion on cropping areas in 2012, representing the situation just before Law 12,787 came into effect in 2013.

Expanding irrigation can be an effective measure to increase agricultural production. Using a spatial explicit modelling tool for the sensible, forward-looking and sustainable planning of expansion areas can be achieved by avoiding an expansion in areas where high water scarcity would be the consequence. This applies in particular to the Cerrado biome. Moreover, the temporal variations regarding crop water requirements have been addressed by process-oriented modelling with respect to the local cropping calendar. This work provides a sound basis for further assessment of water management strategies in order to achieve the nationwide development and implementation of sustainable agricultural policies. 


\section{Appendix A}

Table A1. Crop coefficients $K_{\mathrm{c}}(-)$ and lengths $L(\mathrm{~d})$ of crop development stages of the crops considered in this study.

\begin{tabular}{lrrrrrrr}
\hline Crop & $K_{\text {c,ini }}$ & $K_{\text {c,mid }}$ & $K_{\text {c,end }}$ & $L_{\text {ini }}$ & $L_{\text {dev }}$ & $L_{\text {mid }}$ & $L_{\text {late }}$ \\
\hline Corn $^{\mathrm{a}}$ & 0.65 & 1.1 & 0.6 & 30 & 40 & 50 & 30 \\
Soybean $^{\mathrm{a}}$ & 0.6 & 1.05 & 0.6 & 10 & 40 & 50 & 20 \\
Sugarcane $^{\mathrm{a}}$ & 0.5 & 1.25 & 0.8 & 30 & 60 & 180 & 95 \\
Cassava $^{\mathrm{b}}$ & 0.3 & 0.8 & 0.3 & 20 & 40 & 90 & 60 \\
Rice $^{\mathrm{b}}$ & 1.05 & 1.2 & 0.75 & 30 & 30 & 60 & 30 \\
Cotton $^{\mathrm{b}}$ & 0.35 & 1.2 & 0.6 & 30 & 50 & 55 & 45 \\
Wheat $^{\mathrm{b}}$ & 0.7 & 1.15 & 0.25 & 15 & 30 & 65 & 40 \\
Phaseolus $^{\mathrm{b}}$ & 0.5 & 1.05 & 0.9 & 20 & 30 & 30 & 10 \\
Vigna $^{\mathrm{b}}$ & 0.5 & 1.05 & 0.9 & 20 & 30 & 30 & 10 \\
\hline
\end{tabular}

a Source: Hernandes et al. (2014); ${ }^{\text {b }}$ source: Allen et al. (1998).

Table A2. Planting and harvesting dates (given in the format dd.mm.) of the different crops and the five sub-regions considered in this study (Conab, 2015). Note that "2nd" and "3rd" are the second and third planting dates for double- and triple-cropping within one growing season, i.e. a successive multiple-cropping practice.

\begin{tabular}{lcc|cc|cc|cc|cc}
\hline & \multicolumn{2}{c}{ North } & \multicolumn{2}{c|}{ Northeast } & \multicolumn{2}{c|}{ Centre-West } & \multicolumn{2}{c}{ Southeast } & \multicolumn{2}{c}{ South } \\
\cline { 2 - 9 } Crop & Sowing & Harvest & Sowing & Harvest & Sowing & Harvest & Sowing & Harvest & Sowing & Harvest \\
\hline Cassava & 01.09. & 29.03. & 01.09. & 29.03. & 01.09. & 29.03. & 01.09. & 29.03. & 01.09. & 29.03. \\
Corn & 01.12. & 29.04. & 15.01. & 13.06. & 15.11. & 13.04. & 15.11. & 13.04. & 15.10. & 13.03. \\
Corn, 2nd & 10.04. & 06.09. & 01.05. & 27.09. & 15.02. & 14.07. & 15.03. & 11.08. & 15.02. & 14.07. \\
Cotton & 15.01. & 13.07. & 15.02. & 13.08. & 15.12. & 12.06. & 01.12. & 29.05. & 15.11. & 13.05. \\
Phaseolus spp. & 15.12. & 14.03. & 15.11. & 12.02. & 15.11. & 12.02. & 01.11. & 29.01. & 01.10. & 29.12. \\
Phaseolus, 2nd & 01.04. & 29.06. & 01.03. & 29.05. & 15.02. & 15.05. & 01.03. & 29.05. & 01.02. & 01.05. \\
Phaseolus, 3rd & 15.05. & 12.08. & 15.05. & 12.08. & 15.05. & 12.08. & 01.05. & 29.07. & 01.05. & 29.07. \\
Rice & 15.11. & 13.04. & 01.01. & 30.05. & 15.11. & 13.04. & 15.11. & 13.04. & 01.11. & 30.03. \\
Soybean & 01.12. & 30.03. & 01.12. & 30.03. & 15.11. & 14.03. & 15.11. & 14.03. & 15.11. & 14.03. \\
Sugarcane & 01.10. & 30.09. & 01.10. & 30.09. & 01.07. & 30.06. & 01.07. & 30.06. & 01.07. & 30.06. \\
Vigna spp. & 15.12. & 14.03. & 15.11. & 12.02. & 15.11. & 12.02. & 01.11. & 29.01. & 01.10. & 29.12. \\
Vigna spp., 2nd & 01.04. & 29.06. & 01.03. & 29.05. & 15.02. & 15.05. & 01.03. & 29.05. & 01.02. & 01.05. \\
Vigna spp., 3rd & 15.05. & 12.08. & 15.05. & 12.08. & 15.05. & 12.08. & 01.05. & 29.07. & 01.05. & 29.07. \\
Wheat & 15.04. & 11.09. & 15.04. & 11.09. & 15.04. & 11.09. & 01.05. & 27.09. & 15.06. & 11.11. \\
\hline
\end{tabular}


Grid level: environmental input data

- Climate $\left(0.25^{\circ} \times 0.25^{\circ}\right)$

- $\quad$ Soil $(1 \mathrm{~km} \times 1 \mathrm{~km})$

Aggregated to ...

$\downarrow$

Micro-basin level: water consumption and supply

Field crop water balance by SPARE:WATER

Data on physical water availability from river runoff

Aggregated to ...

$\downarrow$

Municipality level: crop production statistics and water scarcity assessment

- $\quad$ Extent of irrigated areas

- $\quad$ Fraction of irrigation per crop

- $\quad$ Crop production

- $\quad$ Crop water consumption based on SPARE:WATER

- Water scarcity/ sustainability assessment

Figure A1. Spatial aggregation steps in the analysis. 
Code availability. The code written for this analysis can be made available by the first author upon request.

Data availability. Data used in this study are available from the following sources: climate data (Xavier et al., 2016) from http://careyking.com/data-downloads/, soil data (Hengl et al., 2014) from https://www.isric.org/explore/soilgrids, crop data (IBGE, 2012) from http://www.sidra.ibge.gov.br/, the extent of irrigated areas (IBGE, 2012) from http://www.sidra.ibge.gov. $\mathrm{br} /$, the fraction of irrigated area per crop (IBGE, 2006) from http://www.sidra.ibge.gov.br/ and the surface water supply (ANA, 2016) from http://metadados.ana.gov.br/geonetwork/srv/pt/ metadata.show?id=307. Other data used here, but not accessible online, can be accessed via the references listed in the references section.

Author contributions. MP, QdJvL and MSK initiated the study. SM and MP jointly developed the concept and methodology, with contributions by MSK and LB. SM, MP, ALCA and AGOPB preprocessed the input data for the analysis. SM carried out the calculations and prepared the figures. SM, MP, MSK and LB analysed the results. SM, MP and MSK wrote the first draft of the paper. The final version of the paper has been prepared based on revisions that have been contributed by all authors.

Competing interests. The authors declare that they have no conflict of interest.

Acknowledgements. The authors would like to thank the three anonymous reviewers and the editor for their valuable comments and suggestions which helped improve the paper.

Financial support. This research has been supported by the Netherlands Organisation for Scientific Research (NWO, the Netherlands) (grant no. 729.004.014) and the National Council of Technological and Scientific Development (CNPq, Brazil) (grant no. 456387/2013-7).

This open-access publication was funded by Justus Liebig University.

Review statement. This paper was edited by Nunzio Romano and reviewed by three anonymous referees.

\section{References}

Abdi, R. and Yasi, M.: Evaluation of environmental flow requirements using eco-hydrologic-hydraulic methods in perennial rivers, Water Sci. Technol., 72, 354-363, https://doi.org/10.2166/wst.2015.200, 2015.
Abe, C. A., Lobo, F. L., Dibike, Y. B., Costa, M. P. F., Dos Santos, V., and Novo, E. M. L. M.: Modelling the effects of historical and future land cover changes on the hydrology of an Amazonian Basin, Water, 10, 932, https://doi.org/10.3390/w10070932, 2018.

Alkimim, A., Sparovek, G., and Clarke, K. C.: Converting Brazil's pastures to cropland: an alternative way to meet sugarcane demand and to spare forestlands, Appl. Geogr., 62, 75-84, https://doi.org/10.1016/j.apgeog.2015.04.008, 2015.

Allen, R. G., Pereira, L. S., Raes, D., and Smith, M.: Crop evapotranspiration-guidelines for computing crop water requirements, FAO Irrigation and drainage paper 56, Food and Agriculture Organization of the United Nations, Rome, Italy, 1998.

ANA: Conjuntura dos recursos hídricos no Brasil, Informe 2015, Agência Nacional de Águas, Brasília, Brazil, 88 pp., ISBN 97885-8210-030-1, 2015.

ANA: Disponibilidade Hídrica Superficial, Agência Nacional de Águas, Brasília, Brazil, available at: http://metadados.ana. gov.br/geonetwork/srv/pt/metadata.show?id=307 (last access: 25 November 2019), 2016.

ANA: Levantamento da agricultura irrigada por pivôs centrais no Brasil, Agência Nacional de Águas, Embrapa Milho e Sorgo, 2nd edn., Brasília, Brazil, 47 pp., ISBN 978-85-8210-060-8, 2019.

Arvor, D., Dubreuil, V., Ronchail, J., Simões, M., and Funatsu, B.M.: Spatial patterns of rainfall regimes related to levels of double cropping agriculture systems in Mato Grosso (Brazil), Int. J. Climatol. 34, 2622-2633, https://doi.org/10.1002/joc.3863, 2014.

Berger, M., van der Ent, R., Eisner, S., Bach, V., and Finkbeiner, M.: Water accounting and vulnerability evaluation (WAVE): Considering atmospheric evaporation recycling and the risk of freshwater depletion in water footprinting, Environ. Sci. Technol., 48, 4521-4528, https://doi.org/10.1021/es404994t, 2014.

Bosznay, M.: Generalization of SCS curve number method, J. Irrig. Drain. Eng., 115, 139-144, 1989.

Boulay, A., Bare, J., Benini, L., Berger, M., Lathuillière, M. J., Manzardo, A., Margni, M., Motoshita, M., Núñez, M., Pastor, A. V., Ridoutt, B., Oki, T., Worbe, S., and Pfister, S.: The WULCA consensus characterization model for water scarcity footprints: assessing impacts of water consumption based on available water remaining (AWARE), Int. J. Life Cycle Ass., 23, 368-378, https://doi.org/10.1007/s11367-017-1333-8, 2018.

Castello, L. and Macedo, M. N.: Large-scale degradation of Amazonian freshwater ecosystems, Glob. Change Biol., 22, 990-1007, 2016.

Chukalla, A. D., Krol, M. S., and Hoekstra, A. Y.: Green and blue water footprint reduction in irrigated agriculture: effect of irrigation techniques, irrigation strategies and mulching, Hydrol. Earth Syst. Sci., 19, 4877-4891, https://doi.org/10.5194/hess-19-48772015, 2015.

Cohn, A. S., VanWey, L. K., Spera, S. S, and Mustard, J. F.: Cropping frequency and area response to climate variability can exceed yield response, Nat. Clim. Change, 6, 601-604, 2016.

Conab: Acomp. Safra bras. grãos, v. 2 - Safra 2014/15, no. 10 - Décimo levantamento, Brasília, 1-109, Companhia Nacional de Abastecimento, Observatório Agrícola, Brasília, Brasil, ISSN 2318-6852, 2015.

Dalin, C., Konar, M., Hanasaki, N., Rinaldo, A., and Rodriguez-Iturbe, I.: Evolution of the global virtual water 
trade network, P. Natl. Acad. Sci. USA, 109, 5989-5994, https://doi.org/10.1073/pnas.1203176109, 2012.

Damkjaer, S. and Taylor, R.: The measurement of water scarcity: Defining a meaningful indicator, Ambio, 46, 513-531, 2017.

da Silva, V. D. P. R., De Oliveira, S. D., Hoekstra, A. Y., Dantas Neto, J., Campos, J. H. B. C., Braga, C. C., De Araújo, L. E., Aleixo, D. D. O., De Brito, J. I. B., De Souza, M. D., and De Holanda, R. M.: Water footprint and virtual water trade of Brazil, Water, 8, 517, https://doi.org/10.3390/w8110517, 2016.

Dickie, A., Magno, I., Giampietro, J., and Dolginow, A.: Challenges and opportunities for conservation, agricultural production, and social inclusion in the Cerrado biome, CEA Consulting, San Francisco, USA, 54 pp., 2016.

Dos Santos, V., Laurent, F., Abe, C., and Messner, F.: Hydrologic response to land use change in a large basin in Eastern Amazon, Water, 10, 429, https://doi.org/10.3390/w10040429, 2018.

Fachinelli, N. P. and Pereira Jr., A. O.: Impacts of sugarcane ethanol production in the Paranaiba basin water resources, Biomass Bioenerg., 83, 8-16, https://doi.org/10.1016/j.biombioe.2015.08.015, 2015.

Fader, M., Gerten, D., Thammer, M., Heinke, J., Lotze-Campen, H., Lucht, W., and Cramer, W.: Internal and external green-blue agricultural water footprints of nations, and related water and land savings through trade, Hydrol. Earth Syst. Sci., 15, 1641-1660, https://doi.org/10.5194/hess-15-1641-2011, 2011.

Falkenmark, M.: Land-water linkages: a synopsis, in: FAO, Land and water integration and river basin management, Proceedings of an FAO informal workshop, 31 January-2 February 1993, Rome, Italy, FAO Land and Water Bulletin 1, Food and Agriculture Organization, Rome, Italy, 15-16, 1995.

FEALQ/IICA/MI: Integrated spatial analysis for development of irrigated agriculture in Brazil. Luiz de Queiroz Agricultural Studies Foundation/Inter-American Institute for Cooperation on Agriculture/Ministry of $\mathrm{Na}$ tional Integration, Technical Cooperation Program PCT BRA/IICA/08/002, available at: http://www.mi.gov.br/ analise-territorial-para-o-desenvolvimento-da-agricultura-irrigada (last access: 25 November 2019), 2015 (in Portuguese).

Flach, R., Ran, Y., Godar, J., Karlberg, L., and Suavet, C.: Towards more spatially explicit assessments of virtual water flows: Linking local water use and scarcity to global demand of Brazilian farming commodities, Environ. Res. Lett., 11, 075003 , https://doi.org/10.1088/1748-9326/11/7/075003, 2016.

Gerbens-Leenes, W. and Hoekstra, A. Y.: The water footprint of sweeteners and bio-ethanol, Environ. Int., 40, 202-211, 2012.

Getirana, A.: Extreme water deficit in Brazil detected from space, J. Hydrometeorol., 17, 591-599, 2016.

Hengl, T., de Jesus, J. M., MacMillan, R. A., Batjes, N. H., Heuvelink, G. B. M., Ribeiro, E., Samuel-Rosa, A., Kempen, B., Leenaars, J. G. B., Walsh, M. G., and Ruiperez Gonzalez, M.: SoilGrids1km - Global Soil Information Based on Automated Mapping, PLoS ONE, 9, e105992, https://doi.org/10.1371/journal.pone.0105992, 2014 (data available at: https://www.isric.org/explore/soilgrids, last access: 25 November 2019).

Hernandes, T. A., Bufon, V. B., and Seabra, J. E.: Water footprint of biofuels in Brazil: assessing regional differences, Biofuel. Bioprod. Bior., 8, 241-252, https://doi.org/10.1002/bbb.1454, 2014.
Hoekstra, A. Y., Mekonnen, M. M., Chapagain, A. K., Mathews, R. E., and Richter, B. D.: Global monthly water scarcity: Blue water footprints versus blue water availability, PLoS One 7, e32688. https://doi.org/10.1371/journal.pone.0032688, 2012.

IBGE: Censo Agropecuário 2006. Instituto Brasileiro de Geografia e Estatística, Rio de Janeiro, Brazil, available at: http://www. sidra.ibge.gov.br/ (last access: 25 November 2019), 2006.

IBGE: Produção Agrícola Municipal. Instituto Brasileiro de Geografia e Estatística, Rio de Janeiro, Brazil, available at: http: //www.sidra.ibge.gov.br/ (last access: 25 November 2019), 2012.

Jägermeyr, J., Gerten, D., Heinke, J., Schaphoff, S., Kummu, M., and Lucht, W.: Water savings potentials of irrigation systems: global simulation of processes and linkages, Hydrol. Earth Syst. Sci., 19, 3073-3091, https://doi.org/10.5194/hess-19-3073-2015, 2015.

Jägermeyr, J., Gerten, D., Schaphoff, S., Heinke, J., Lucht, W., and Rockström, J.: Integrated crop water management might sustainably halve the global food gap, Environ. Res. Lett., 11, 25002, https://doi.org/10.1088/1748-9326/11/2/025002, 2016.

Książek, L., Woś, A., Florek, J., Wyrębek, M., Młyński, D., and Wałega, A.: Combined use of the hydraulic and hydrological methods to calculate the environmental flow: Wisloka river, Poland: case study, Environ. Monit. Assess., 191, 254, https://doi.org/10.1007/s10661-019-7402-7, 2019.

Lathuillière, M. J., Coe, M. T., and Johnson, M. S.: A review of green- and blue-water resources and their trade-offs for future agricultural production in the Amazon Basin: what could irrigated agriculture mean for Amazonia?, Hydrol. Earth Syst. Sci., 20, 2179-2194, https://doi.org/10.5194/hess-20-2179-2016, 2016.

Lathuillière, M. J., Dalmagro, H. J., Black, T. A., Arruda, P. H. Z. d., Hawthorne, I., Couto, E. G., and Johnson, M. S.: Rain-fed and irrigated cropland-atmosphere water fluxes and their implications for agricultural production in Southern Amazonia, Agr. Forest Meteorol., 256-257, 407-419, https://doi.org/10.1016/j.agrformet.2018.03.023, 2018.

Mekonnen, M. M. and Hoekstra, A. Y.: A global and highresolution assessment of the green, blue and grey water footprint of wheat, Hydrol. Earth Syst. Sci., 14, 1259-1276, https://doi.org/10.5194/hess-14-1259-2010, 2010.

Mittermeier, R. A., Gil, P. R., Hoffman, M., Pilgrim, J., Brooks, T., Mittermeier, C. G., Lamoreux, J., and da Fonseca, G. A. B.: Hotspots revisited-Earth's biologically richest and most endangered terrestrial ecoregions, University of Chicago Press, Chicago, IL, USA, 2005.

Multsch, S., Al-Rumaikhani, Y. A., Frede, H.-G., and Breuer, L.: A Site-sPecific Agricultural water Requirement and footprint Estimator (SPARE:WATER 1.0), Geosci. Model Dev., 6, 1043-1059, https://doi.org/10.5194/gmd-6-1043-2013, 2013.

Multsch, S., Pahlow, M., Ellensohn, J., Michalik, T., Frede, H.-G., and Breuer, L.: A hotspot analysis of water footprints and groundwater decline in the High Plains aquifer region, USA, Reg. Environ. Change, 16, 2419-2428, https://doi.org/10.1007/s10113-016-0968-5, 2016.

Multsch, S., Elshamy, M. E., Batarseh, S., Seid, A. H., Frede, H.G., and Breuer, L.: Improving irrigation efficiency will be insufficient to meet future water demand in the Nile Basin, J. Hydrol., Regional Studies, 12, 315-30, 2017a. 
Multsch, S., Grabowski, D., Lüdering, J., Alquwaizany, A. S., Lehnert, K., Frede, H.-G., Winker, P., and Breuer, L.: A practical planning software program for desalination in agriculture - SPARE:WATERopt, Desalination, 404, 121-131, https://doi.org/10.1016/j.desal.2016.11.012, $2017 \mathrm{~b}$.

Pereira, L. S., Oweis, T., and Zairi, A.: Irrigation management under water scarcity, Agr. Water. Manage., 57, 175-206, https://doi.org/10.1016/S0378-3774(02)00075-6, 2002.

Pereira, L. S., Allen, R. G., Smith, M., and Raes, D.: Crop evapotranspiration estimation with FAO56: Past and future, Agr. Water Manag., 147, 4-20, https://doi.org/10.1016/j.agwat.2014.07.031, 2015.

Raskin, P., Gleick, P. H., Kirshen, P., Pontius Jr., R. G., and Strzepek, K.: Comprehensive assessment of the freshwater resources of the world, Stockholm Environmental Institute, Stockholm, Sweden, p. 51, 1997.

Richter, B. D., Davis, M. M., Apse, C., and Konrad, C.: A presumptive standard for environmental flow protection, River Res. Appl., 28, 1312-1321, https://doi.org/10.1002/rra.1511, 2012.

Rockström, J., Karlberg, L., Wani, S. P., Barron, J., Hatibu, N., Oweis, T., Bruggeman, A., Farahani, J., and Qiang, Z.: Managing water in rainfed agriculture - The need for a paradigm shift, Agr. Water Manage., 97, 543-550, https://doi.org/10.1016/j.agwat.2009.09.009, 2010.

Rodrigues, L. N., Sano, E. E., Steenhuis, T. S., and Passo, D. P.: Estimation of small reservoir storage capacities with remote sensing in the Brazilian Savannah region, Water Resour. Manag., 26, 873-882, https://doi.org/10.1007/s11269-011-9941-8, 2012.

Rost, S., Gerten, D., Hoff, H., Lucht, W., Falkenmark, M., and Rockström, J.: Global potential to increase crop production through water management in rainfed agriculture, Environ. Res. Lett., 4, 44002, https://doi.org/10.1088/1748-9326/4/4/044002, 2009.

Scarpare, F. V., Hernandes, T. A. D., Ruiz-Corrêa, S. T., Picoli, M. C. A., Scanlon, B. R., Chagas, M. F., Duft, D. G., and de Fatima Cardoso, T.: Sugarcane land use and water resources assessment in the expansion area in Brazil, J. Clean. Prod., 133, 1318-1327, 2016.

Siebert, S. and Döll, P.: Quantifying blue and green virtual water contents in global crop production as well as potential production losses without irrigation, J. Hydrol., 384, 198-217, 2010.

Smakhtin, V., Revenga, C., and Döll, P.: A pilot global assessment of environmental water requirements and scarcity, Water International, 29, 307-317, https://doi.org/10.1080/02508060408691785, 2004.

Sparovek, G., Barretto, A. G. O. P., Matsumoto, M., and Berndes, G.: Effects of governance on availability of land for agriculture and conservation in Brazil, Environ. Sci. Technol., 49, 1028510293, 2015.

Spera, S. A.: Agricultural intensification can preserve the Brazilian Cerrado: Applying lessons from Mato Grosso and Goiás to Brazil's last agricultural frontier, Trop. Conserv. Sci., 10, 1-7, https://doi.org/10.1177/1940082917720662, 2017.
Spera, S. A., Galford, G. L., Coe, M. T., Macedo, M. N., and Mustard, J. F.: Land-use change affects water recycling in Brazil's last agricultural frontier, Glob. Change Biol., 22, 3405-3413, https://doi.org/10.1111/gcb.13298, 2016.

Strassburg, B. B. N., Latawiec, A. E., Barioni, L. G., Nobre, C. A., da Silva, V. P., Valentim, J. F., Vianna, M., and Assad, E. D.: When enough should be enough: Improving the use of current agricultural lands could meet production demands and spare natural habitats in Brazil, Global Environ. Chang., 28, 84-97, 2014.

Strassburg, B. B. N., Brooks T., Feltran-Barbieri R., Iribarrem A., Crouzeilles R., Loyola R., Latawiec A. E., Oliveira Filho F. J., de M. Scaramuzza, C. A., Scarano, F. R., Soares-Filho, B., and Balmford, A.: Moment of truth for the Cerrado hotspot, Nat. Ecol. Evol., 1, 0099, https://doi.org/10.1038/s41559-017-0099, 2017.

Tennant, D. L.: Instream flow regimens for fish, wildlife, recreation and related environmental resources, Fisheries 1, 6-10, 1976.

Tomasella, J., Hodnett, M. G., and Rossato, L.: Pedotransfer functions for the estimation of soil water retention in Brazilian soils, Soil Sci. Soc. Am. J., 64, 327-38, 2000.

UN: Comprehensive assessment of the freshwater resources of the world. Report of the Secretary General, Report E/CN.17/1997/9, United Nations, New York, NY, USA, 1997.

Van Genuchten, M. T.: A closed form equation for predicting the hydraulic conductivity of unsaturated soils, Soil Sci. Soc. Am. J., 44, 892-898, 1980.

Vanham, D., Hoekstra, A. Y., Wada, Y., Bouraoui, F., de Roo, A., Mekonnen, M. M., van de Bund, W. J., Batelaan, O., Pavelic, P., Bastiaanssen, W. G. M., Kummu, M., Rockström, J., Liu, J., Bisselink, B., Ronco, P., Pistocchi, A., and Bidoglio, G.: Physical water scarcity metrics for monitoring progress towards SDG target 6.4: An evaluation of indicator 6.4.2 "Level of water stress", Sci. Total Environ., 613-614, 218-232, https://doi.org/10.1016/j.scitotenv.2017.09.056, 2018.

VanWey, L. K., Spera, S., de Sa, R., Mahr, D., and Mustard, J. F.: Socioeconomic development and agricultural intensification in Mato Grosso, Philos. T. Roy. Soc. A, 368, 20120168, https://doi.org/10.1098/rstb.2012.0168, 2013.

Wriedt, G., Van der Velde, M., Aloe, A., and Bouraoui, F.: Estimating irrigation water requirements in Europe, J. Hydrol., 373, 527-544, 2009.

Xavier, A. C., King, C. W., and Scanlon, B. R.: Daily gridded meteorological variables in Brazil (1980-2013), Int. J. Climatol., 36, 2644-2659, https://doi.org/10.1002/joc.4518, 2016 (data available at: http://careyking.com/data-downloads/, last access: 25 November 2019). 